\title{
What on earth did I do with my pen?
}

\author{
Sophie Lumley, ${ }_{1}^{1}$ Arvind Pallan, ${ }^{2}$ Craig Checkley, ${ }^{3}$ Olga Noreen Tucker ${ }^{4,5}$
}

${ }^{1}$ Department of General Medicine, Queen Elizabeth Hospital, Birmingham, UK ${ }^{2}$ Department of Radiology, Queen Elizabeth Hospital, Birmingham, UK

${ }^{3}$ Department of Surgery, Queen Elizabeth Hospital,

Birmingham, UK

${ }^{4}$ Heart of England NHS Foundation Trust, Birmingham, UK

${ }^{5}$ Department of Surgery, University of Birmingham, Birmingham, UK

\section{Correspondence to} Dr Sophie Lumley, sophielumley@doctors.org.uk

Accepted 16 June 2016
CrossMark

To cite: Lumley $S$, Pallan $A$, Checkley C, et al. BMJ Case Rep Published online: [please include Day Month Year] doi:10.1136/bcr-2016215222

\section{DESCRIPTION}

A 38-year-old woman was admitted acutely from an inpatient psychiatric unit with a history of right loin to groin pain 1 day following vaginal instrumentation with a bottle. Her medical history included diabetes mellitus, cholecystectomy and borderline personality disorder with a history of self-harm.

She was feverish with generalised abdominal tenderness. The cervix and vagina were healthy with no discharge and no foreign body. Investigations revealed raised inflammatory markers, and normal transabdominal ultrasound scan, chest and pelvic
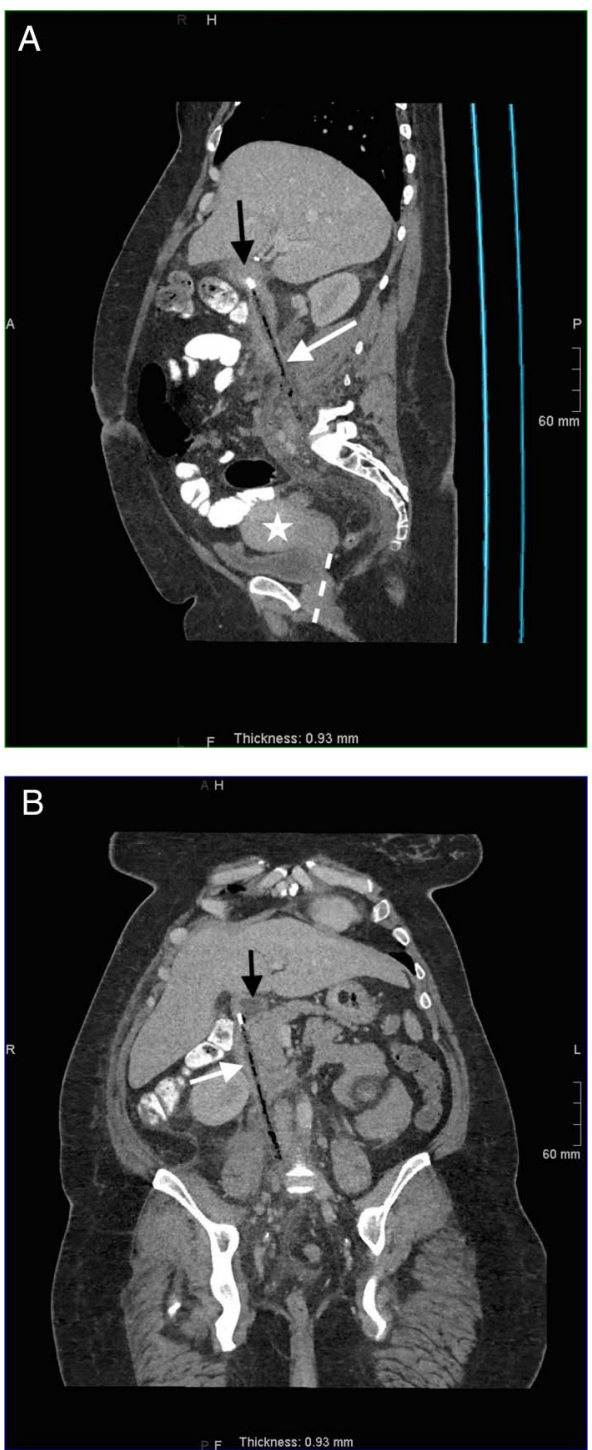

Figure 1 Oblique sagittal (A) and coronal (B) reconstructions of $\mathrm{CT}$ demonstrating the retroperitoneal foreign body (white arrow). The metallic tip lies just below the duodenum (black arrow). The long axis of the vagina (dashed line) and position of the uterine fundus (white star) are marked.
X-rays. An abdominopelvic CT scan demonstrated two foreign bodies, in the right retroperitoneum, penetrating into the second part of the duodenum (D2) and in the stomach (figures $1 \mathrm{~A}, \mathrm{~B}$ and 2). At endoscopy, the tip of a pen was seen entering D2, traversing the lumen and buried within the posterior wall, and a beheaded toothbrush was seen in the stomach. Careful transoral endoscopic removal of the objects was achieved in line with recent European Society of Gastrointestinal Endoscopy guidelines on removal of foreign bodies in the upper gastrointestinal tract, followed by an uneventful recovery. ${ }^{1}$

The likely route of foreign body entry was transoral. However, as the tip of the pen was visualised penetrating into D2 with a clear tract on CT imaging extending from the pelvis through the right retroperitoneum, vaginal insertion was considered.

Insertion of foreign bodies into bodily orifices is common. ${ }^{2}$ However, there are few documented reports of objects migrating to the upper abdominal cavity following vaginal insertion. Intrauterine contraceptive devices have been reported adjacent to the liver, following transperitoneal migration. ${ }^{3}$

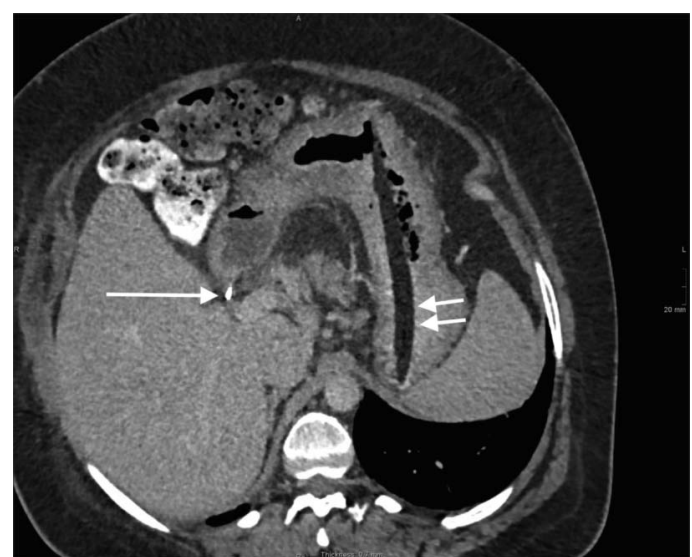

Figure 2 Oblique axial reconstruction of CT demonstrating the second intragastric foreign body (white double arrow). The metallic pen tip is visible (single white arrow).

\section{Learning points}

Always consider self-harm as a cause for atypical symptoms and signs in patients with a previous history.

- Detailed examination of the radiological anatomy can assist in identifying potential routes of access of instrumented foreign bodies, which can aid in removal planning.

- The improbable is still possible. 
Contributors SL wrote the original article and subsequently led on redrafting. ONT conducted the procedure outlined in the article and helped with redrafting. AP was the radiologist who reported the CT scans included in the article. CC assisted in the removal of the objects outlined in the article. All the authors contributed to final drafting of the article.

Competing interests None declared.

Patient consent Obtained.

Provenance and peer review Not commissioned; externally peer reviewed.

\section{REFERENCES}

1 Birk M, Bauerfeind P, Deprez PH, et al. Removal of foreign bodies in the upper gastrointestinal tract in adults: European Society of Gastrointestinal Endoscopy (ESGE) Clinical Guideline. Endoscopy 2016:48:489-96.

2 Emara MH, Darwiesh EM, Refaey MM, et al. Endoscopic removal of foreign bodies from the upper gastrointestinal tract: 5 year experience. Clin Exp Gastroenterol 2014;7:249-53.

3 Bitterman A, Lefel O, Segev $Y$, et al. Laparoscopic removal of an intrauterine device following colon perforation. JSLS 2010;14:456-8.

Copyright 2016 BMJ Publishing Group. All rights reserved. For permission to reuse any of this content visit http://group.bmj.com/group/rights-licensing/permissions.

BMJ Case Report Fellows may re-use this article for personal use and teaching without any further permission.

Become a Fellow of BMJ Case Reports today and you can:

- Submit as many cases as you like

- Enjoy fast sympathetic peer review and rapid publication of accepted articles

- Access all the published articles

- Re-use any of the published material for personal use and teaching without further permission

For information on Institutional Fellowships contact consortiasales@bmjgroup.com

Visit casereports.bmj.com for more articles like this and to become a Fellow 